\title{
Response of the Peanut (Arachis hypogaea L.) Cultivar Gregory to Interactions of Digging Date and Disease Management
}

\author{
David L. Jordan, ${ }^{1}$ Barbara B. Shew, ${ }^{2}$ and P. Dewayne Johnson ${ }^{1}$ \\ ${ }^{1}$ Department of Crop and Soil Sciences, North Carolina State University, Box 7620, Raleigh, NC 27695-7620, USA \\ ${ }^{2}$ Department of Plant Pathology and Entomology, North Carolina State University, Box 7903, Raleigh, NC 27695, USA \\ Correspondence should be addressed to David L. Jordan; david_jordan@ncsu.edu
}

Received 11 April 2016; Accepted 28 July 2016

Academic Editor: Ayman Suleiman

Copyright (c) 2016 David L. Jordan et al. This is an open access article distributed under the Creative Commons Attribution License, which permits unrestricted use, distribution, and reproduction in any medium, provided the original work is properly cited.

\begin{abstract}
Digging date can have a major impact on pod yield, market grade characteristics, and economic return of peanut (Arachis hypogaea L.) and can be influenced by environmental conditions and disease management. In 17 experiments from 2003 to 2012, economic return of peanut was determined over 5 digging dates spaced 1 week apart beginning in early to mid-September through midOctober. Linear, quadratic, and cubic relationships for economic return versus days after peanut emergence were observed in 3, 6, and 4 experiments, respectively, with no response to digging date observed in 4 experiments. In a second experiment from 2005 to 2012, relationships among canopy defoliation and economic return for peanut at 3 digging dates with 3 fungicide regimes were variable, although increasing the number of fungicide sprays decreased canopy defoliation and increased economic return for later digging dates. Applying a single late-season spray of fungicide as a rescue treatment reduced canopy defoliation in 4 of 8 years and affected economic value in 2 of 8 years.
\end{abstract}

\section{Introduction}

The timing of digging pods and inverting vines can have a major impact on yield and market grade characteristics of peanut and is related to pod and kernel development [15]. The indeterminate growth habit of peanut creates a wide range of pod and kernel development over the growing season [6]. Mixon and Branch [7] reported that delaying digging by 10 days over a period of 110 to 140 days after planting increased yield, percentage of total sound mature kernels, and economic value of peanut. Sanders et al. [8] demonstrated that $75 \%$ mature fruit resulted in optimum economic value of peanut. Using pod mesocarp color as an indicator, optimum pod and kernel development occurs when the combination of brown and black pod mesocarp color is approximately $75 \%[8,9]$. Once kernels and pods reach this percentage of brown and black color, peanut pods will continue to shed from the plant due to natural physiological processes.

Other physiological measurements and environmental conditions have been explored to define the relationship of pod and kernel development and optimum yield and economic value to assist practitioners in determining when to dig pods and invert vines $[10,11]$. For example, thermal data in the form of heat unit accumulation or recording the days from emergence of peanut until digging are tools farmers use to determine when to initiate digging [11]. However, heat unit accumulation and days after emergence can be confounded by rainfall patterns that hasten or delay development even though heat units continue to accumulate. Rowland et al. [11] reported that a combination of heat unit accumulation and rainfall was a better predictor of optimum maturity than thermal data alone and that pod mesocarp color determination continues to be an essential consideration in determining when to dig pods and invert vines. In addition to thermal and soil moisture influences on pod yield and market grade characteristics, plant health, most notably disease, can hasten plant senescence and pod shed and subsequent yield loss [12].

Optimum peanut yield, market grade characteristics, and economic return are realized when an effective fungicide program is implemented [12-16]. Leaf spot disease (caused by 
the fungi Cercospora arachidicola and Cercosporidium personatum) and stem rot (caused by Sclerotium rolfsii Sacc.) are important diseases in peanut and require protection from the R3 stage of peanut [6] until digging and vine inversion [15]. In North Carolina, farmers treat peanut 4 to 5 times based on weather conditions and disease presence [15]. However, in some years farmers are unable to or decide not to apply fungicides routinely and this can result in epidemics developing in the peanut canopy. In years where excessive rainfall occurs, farmers may be unable to treat peanut with fungicides and/or may not be able to dig peanut in a timely manner. The effectiveness of a single fungicide application late in the season as a rescue treatment has not been evaluated with Virginia market type peanut.

Interactions of cultivar and digging date [1] as well as digging date and disease management have been evaluated in Florida [12], North Carolina [13], and South Carolina [14] but not in recent years with newer cultivars. Yield loss when leaf spot was prevalent resulted from an increase in the rate of pod shed [12]. Farmers are required to strike a balance between digging prior to optimum maturity and delaying digging until optimum maturity is reached with the risk of delays in digging due to environmental conditions resulting in pod shed and yield loss. Therefore, research was conducted in North Carolina with the cultivar Gregory, a relatively popular Virginia market type cultivar grown during the recent decade, to determine relationships of pod yield, market grade quality, and economic value with digging dates and to define interactions of fungicide regimes and digging date.

\section{Materials and Methods}

2.1. General Methods for All Experiments. Experiments were conducted at the Peanut Belt Research Station located near Lewiston-Woodville $(36.07 \mathrm{~N},-77.11 \mathrm{~W})$ on a mix of Norfolk loamy sand soil (fine-loamy, kaolinitic, thermic Typic Kandiudults) and a Goldsboro loamy sand soil (fine-loamy, siliceous, subactive, thermic Aquic Paleudults) in conventionally prepared raised seed beds. Plot size was 2 rows wide $(91 \mathrm{~cm})$ by $11 \mathrm{~m}$ long. The Virginia market type cultivar Gregory [17] was planted at an in-row rate of 17 seeds $/ \mathrm{m}$ between May 2 and May 20. Peanut was irrigated periodically in July and August to supplement rainfall to maintain growth and development. The combination of rain and irrigation during each week of both months was approximately $2 \mathrm{~cm}$. Two years of corn (Zea mays L.) or cotton (Gossypium hirsutum L.) separated peanut plantings.

Aldicarb (Temik insecticide, Bayer Crop Science, Research Triangle Park, NC) in the seed furrow at $1.1 \mathrm{~kg}$ ai $/ \mathrm{ha}$ was applied in all experiments to control thrips (Frankliniella spp.). Chlorpyrifos (Lorsban 15G insecticide, Dow AgroSciences, Indianapolis, IN) at $2.4 \mathrm{~kg}$ ai $/$ ha was applied in a $30 \mathrm{~cm}$ band over the row at the R2 [6] stage of growth approximately 40 days after planting to control corn rootworm (Diabrotica undecimpunctata Howardi). S-Metolachlor (Dual II Magnum herbicide, Syngenta Crop Protection, Greensboro, NC) $(0.91 \mathrm{~kg}$ ai $/ \mathrm{ha})$ was applied over the entire test area in all experiments. Acifluorfen (Ultra Blazer herbicide, BASF Corporation, Research Triangle Park, NC) $(0.42 \mathrm{~kg}$ ai $/ \mathrm{ha})$ plus bentazon (Basagran herbicide, BASF Corporation, Research Triangle Park, NC) (1.7 kg ai/ha) plus 2,4-DB (Butyrac 200 herbicide, Albaugh Inc., Ankeny, IA) $(0.28 \mathrm{~kg} \mathrm{ai} / \mathrm{ha})$ was applied to control escaped broadleaf weeds and sedges when weeds were 2 to $6 \mathrm{~cm}$ in height. Clethodim (Select 2EC herbicide, Valent USA Corp., Walnut Creek, CA) (0.14 kgai/ha) was applied to control escaped annual grasses. Appropriate adjuvants were included with postemergence herbicides.

Pod yield was determined by harvesting 4-7 days after digging and vine inversion. Final yield was adjusted to $8 \%$ moisture. A $1 \mathrm{~kg}$ sample of pods was collected at harvest to determine market grade characteristics [18] and used to determine economic value as the product of yield and price/ $\mathrm{kg}$. The price was set at $\$ 0.6 / \mathrm{kg}$, the current reference price for Virginia market type peanut in the United States [19].

\subsection{Peanut Response to Five Digging Dates with 5 Fungicide} Sprays for Leaf Spot Disease. A total of 17 trials were conducted from 2003 to 2012 at the Peanut Belt Research Station located near Lewiston-Woodville, NC. Peanut pods were dug and vines inverted beginning between September 7 and 11 and continuing for 4 more dates at weekly intervals.

Fungicides to control stem rot and leaf spot disease consisted of chlorothalonil (Bravo Weather Stik fungicide, Syngenta Crop Protection, Greensboro, NC) (1.23 kg ai/ha) applied at R1 [6] followed by two applications of pyraclostrobin (Headline fungicide, BASF Corporation, Research Triangle Park, NC) (0.17 kg ai/ha) or two applications of tebuconazole (Folicur fungicide, Bayer Crop Science, Research Triangle Park, NC) $(0.21 \mathrm{~kg}$ ai $/ \mathrm{ha})$ depending on year. A final application of chlorothalonil ( $0.50 \mathrm{~kg}$ ai $/ \mathrm{ha})$ was made in early September.

The number of days from peanut emergence to digging was recorded in all experiments. Heat unit accumulation with a base of 13 and ceiling of 35 was calculated as the average temperature per day minus 13 . The heat units for each day were summed for each interval of emergence through digging.

The experimental design was a randomized complete block with four replications. Data for pod yield, percentages of extra large kernels (\%ELK) and total sound mature kernels (\%TSMK), and economic value were subjected to ANOVA for a 17 (trial) $\times 5$ (digging date) treatment structure using the GLM procedure in SAS [20]. Data from individual trials and data pooled over trials for pod yield, \%ELK, \%TSMK, and economic value versus days after emergence and heat unit accumulation were tested for linear, quadratic, and cubic functions using regression procedures in SAS [21]. Pearson correlation coefficients for pod yield, \%ELK, \%TSMK, economic value, days after emergence, and heat unit accumulation were constructed using the correlation procedure in SAS [22].

2.3. Peanut Response to Interactions of Fungicide Regime and Digging Date. The experiment was conducted at the Peanut Belt Research Station near Lewiston-Woodville from 2005 to 
TABLE 1: Pearson correlations for canopy defoliation, pod yield, percentages of extra large kernels (\%ELK) and total sound mature kernels (\%TSMK), economic value, days after peanut emergence, and heat unit accumulation in the experiment for the cultivar Gregory with the first 3 of 5 digging dates or with all 5 digging dates included. Data are pooled over 17 experiments from 2003 to 2012.

\begin{tabular}{|c|c|c|c|c|}
\hline \multirow{2}{*}{ Parameters } & \multicolumn{2}{|c|}{ First 3 digging dates } & \multicolumn{2}{|c|}{ Five digging dates } \\
\hline & $P>F$ & $R^{2}$ & $P>F$ & $R^{2}$ \\
\hline Pod yield versus \%ELK & $<0.0001$ & 0.76 & $<0.0001$ & 0.53 \\
\hline Pod yield versus \% TSMK & 0.0070 & 0.33 & 0.0070 & 0.15 \\
\hline Pod yield versus economic value & $<0.0001$ & 0.96 & $<0.0001$ & 0.96 \\
\hline \%ELK versus \%TSMK & $<0.0001$ & 0.63 & $<0.0001$ & 0.66 \\
\hline Economic value versus \%ELK & $<0.0001$ & 0.84 & $<0.0001$ & 0.66 \\
\hline Economic value versus \%TSMK & $<0.0001$ & 0.57 & $<0.0001$ & 0.42 \\
\hline Pod yield versus heat unit accumulation & $<0.0001$ & 0.28 & 0.0782 & 0.10 \\
\hline Pod yield versus days after emergence & $<0.0001$ & 0.54 & $<0.0001$ & 0.24 \\
\hline Economic value versus heat unit accumulation & $<0.0001$ & 0.34 & 0.0003 & 0.20 \\
\hline Economic value versus days after emergence & $<0.0001$ & 0.62 & $<0.0001$ & 0.39 \\
\hline$\%$ ELK versus heat unit accumulation & $<0.0001$ & 0.30 & $<0.0001$ & 0.33 \\
\hline$\%$ ELK versus days after emergence & $<0.0001$ & 0.63 & $<0.0001$ & 0.61 \\
\hline Heat unit accumulation versus days after emergence & $<0.0001$ & 0.65 & $<0.0001$ & 0.96 \\
\hline
\end{tabular}

2012. Treatments consisted of 3 levels of digging date and 3 levels of fungicide regime. Digging dates were September $20-24$, October 3-7, and October 12-15. Fungicide regimes included (1) a no-fungicide control and (2) chlorothalonil applied at R1 stage [2] followed by pyraclostrobin 2 weeks later. The third fungicide regime included chlorothalonil and pyraclostrobin as described previously followed by two applications of tebuconazole and a final application of chlorothalonil. Additional treatments for the final digging date were chlorothalonil plus pyraclostrobin applied in midSeptember at $0.5 \mathrm{~kg} / \mathrm{ha}$ and $0.11 \mathrm{~kg} / \mathrm{ha}$, respectively. These treatments were designed to serve as a rescue treatment at different levels of disease late in the season. The rescue treatment was applied approximately 6 weeks after the last application of the fungicide regime with only 2 early season sprays and approximately 2 weeks after the fungicide regime receiving 5 sprays during the season. Differences in the time between the final spray for the fungicide regimes, including the no-fungicide control, allowed a range of canopy defoliation to be present when the rescue treatment was applied.

Canopy defoliation was estimated visually the day peanut was dug on a scale of 0 to $100 \%$ where 0 means no loss of leaflets caused by disease and 100 means all leaflets were lost from the plant as a result of disease. The experimental design was randomized complete block 4 replications. Data for canopy defoliation, pod yield, \%ELK, \%TSMK, and economic value were subjected to ANOVA appropriate for 8 (year) $\times$ 3 (digging date) $\times 3$ (fungicide regime) using the GLM procedure in SAS [20]. Data for the rescue treatment were subjected to ANOVA for 8 (year) $\times 3$ (fungicide regime) $\times 2$ (rescue treatment). Means of significant main effects and interactions were separated using Fisher's protected LSD test $(P \leq 0.05)$. Pearson correlation coefficients for canopy defoliation, pod yield, \%ELK, \%TSMK, and economic value were determined using the correlation procedure in SAS [22].

\section{Results and Discussion}

3.1. Peanut Response to Five Digging Dates with 5 Fungicide Sprays for Leaf Spot Disease. The interaction of trial $\times$ digging date was significant for pod yield, \%ELK, \% TSMK, and economic value $(P \leq 0.0001)$. This interaction is not surprising given the number of years and environmental conditions when the trial was conducted. Also, planting date ranged from May 2 to May 20, with digging initiated during the second week of September regardless of planting date. Differences in weather patterns over the period of time that a trial was conducted most likely contributed to growth and development. However, peanut was irrigated during July and August of each year and most likely minimized differences in pod maturation caused by contrasts in soil moisture. Soil conditions for digging and vine inversion were not always ideal and may have contributed to variation in yield and other parameters, irrespective of pod maturation. Peanut pods were dug and vines inverted on a weekly schedule.

Significant correlations for all parameters were observed when considering only the first 3 digging dates or when all 5 digging dates were included in the analyses (Table 1). Correlation coefficients for pod yield and economic value versus \%ELK and \%TSMK as well as pod yield and economic value versus days after emergence and heat unit accumulation were higher than correlation coefficients when all 5 digging dates were included compared with analyses when only the first 3 digging dates were included. Yield and market grade characteristics most often increase in a linear manner until pod yield declines because of the natural process of pod shed [6]. Percentages of ELK and TSMK continue to increase even 
TABLE 2: Frequency of significant regressions $(P \leq 0.05)$ for pod yield, percentages of extra large kernels (\%ELK) and total sound mature kernels (\%TSMK), and economic value versus days after peanut emergence for 17 trials from 2003 to 2015.

\begin{tabular}{lcccc}
\hline $\begin{array}{l}\text { Regression } \\
\text { functions }\end{array}$ & $\begin{array}{c}\text { Pod yield } \\
(\mathrm{kg} / \mathrm{ha})\end{array}$ & $\begin{array}{c}\text { \%ELK } \\
\text { Number of trials }\end{array}$ & $\begin{array}{c}\text { Economic } \\
\text { value }(\$ / \mathrm{ha})\end{array}$ \\
\hline Nonsignificant & 3 & 3 & 3 & 4 \\
Linear & 6 & 7 & 13 & 3 \\
Quadratic & 4 & 5 & 11 & 6 \\
Cubic & 4 & 2 & 0 & 4 \\
\hline
\end{tabular}

though pod yield may decrease because there is no immature peanut remaining on vines. Days after emergence and heat unit accumulation were more highly correlated when all 5 digging dates were included.

The number of trials conducted in this study and the differences in digging dates relative to planting date limit presentation in graphical format. Because pod yield and economic value were highly correlated with \%ELK and \%TSMK, only the data for economic value are presented because this value reflects contributions of pod yield and market grade characteristics (Table 2).

In 4 of 17 trials, linear, quadratic, and cubic functions were not significant for economic value (Tables 2 and 3). A linear function was significant in 3 trials with quadratic and cubic functions significant in 6 and 4 trials, respectively. Variation in response was not unexpected because of contributions of planting date and differences in weather conditions that influence peanut growth and development. To demonstrate this variation, the average and standard deviation for the highest yield, market grade characteristics, economic value, days from emergence to digging, and heat unit accumulation during that time period to obtain the highest yield are presented in Table 4. Of particular note is the variation in days from emergence and heat unit accumulation required to obtain the highest yield. Considerable research has been conducted to determine the most effective way to use weather data, primarily temperature, and water through irrigation or rainfall, to predict the optimum digging date $[9,11]$. While addressing these parameters was beyond the scope of the present study, our results determined a significant but not necessarily close relationship between economic return and days after emergence or heat unit accumulation relative to digging. The number of days after emergence was a more effective predictor of economic return than heat unit accumulation (Table 1). Regardless, variation suggests that careful attention to pod maturation using the hull scrape method continues to be an important approach to optimizing yield and economic return $[9,11]$.

\subsection{Peanut Response to Interactions of Fungicide Regime} and Digging Date. With the exception of pod yield versus economic value $\left(R^{2}=0.92\right)$ and economic value versus \%ELK $\left(R^{2}=0.61\right)$ or $\%$ TSMK $\left(R^{2}=0.45\right)$, correlation coefficients were relatively low (Table 5). These results are indicative of the relationship of pod yield, \%ELK, and \%TSMK with economic value and disease. In the absence of significant disease incidence, yield response and market grade characteristics are often more highly correlated (Table 1) than observed in this experiment where considerable canopy defoliation was noted. Pod shed is often exacerbated due to canopy defoliation and can affect relationships of yield, market grade characteristics, and economic value in an unpredictable manner.

The interaction trial $\times$ digging date $\times$ fungicide regime was significant for canopy defoliation, pod yield, and economic value (Table 6). This interaction was not significant for \%ELK or \%TSMK. The main effect of digging date was significant for \%ELK and \%TSMK while the main effect of fungicide regime was significant only for \%ELK. Consistent with the experiment evaluating 5 digging dates without disease, delaying digging resulted in an increase in these parameters. Increasing the number of fungicide sprays also increased \%ELK (data not presented). In order to simplify presentation of results, data for economic value will be presented. These data are reflective of the combined effects of yield and market grade characteristics.

When analyzed by year, the interaction of digging date $x$ fungicide regime was significant for canopy defoliation during 2005, 2006, 2008, and 2011 (Table 7). In 2007 when disease incidence was relatively low, main effects and interactions were not significant for canopy defoliation. During 2012 main effects of digging date and fungicide regime were significant while the main effects of fungicide regime and digging date were significant during 2009 and 2010, respectively.

Canopy defoliation for nontreated peanut ranged from 8 to $41 \%$ during $2005,2006,2008$, and 2011 when peanut was dug in late September or early October compared to 59 to $79 \%$ defoliation when peanut was dug in late October (Table 8). When two sprays were included early in the season, the range of defoliation was 1 to $15 \%$ in late September compared with 15 to $26 \%$ by early October. By mid-October, defoliation ranged from 31 to $74 \%$. Including 5 sprays resulted in the least amount of canopy defoliation in some but not all years with a range of 0 to $4 \%$. Canopy defoliation differed between the nontreated control and 2 sprays in 2006 and 2011 at the first digging date but not during 2005 or 2008 (Table 8). By early October, canopy defoliation was lower following 2 sprays compared with nontreated peanut in all years while defoliation differed between these treatments at the final digging date during 2005 and 2011. In 2009 and 2012, increasing the number of sprays from 0 to 2 or 5 decreased canopy defoliation. No difference in defoliation during these years was observed when comparing fungicide regimes containing 2 or 5 sprays (Table 9).

Differences in economic value mirrored differences in canopy defoliation in some but not all comparisons (Tables 8,9 , and 10). During 2008, higher economic value was noted when fungicides were applied regardless of the number of sprays (Table 9). In contrast, during 2010 and 2012 economic value was similar for nontreated peanut and 2 sprays with 5 sprays needed to optimize economic value. During 2005 and 2006, when the interaction of fungicide regime and digging date was significant, the highest economic return was 
TABLE 3: Regression expressions, regression coefficients, and $P>F$ for economic value versus days from peanut emergence to digging from 17 trials conducted during 2003-2012.

\begin{tabular}{lllr}
\hline Experiment & Regression expression & $R^{2}$ & $P>F$ \\
\hline 1 & $Y=20,154 x-142 x^{2}+0.3 x^{3}-942,766$ & 0.79 & $<0.0001$ \\
2 & $Y=-694 x+13,221$ & 0.74 & $<0.0001$ \\
3 & $Y=15,762 x-105 x^{2}+0.3 x^{3}-780,267$ & $<0.0001$ \\
4 & $Y=9,003 x+64 x^{2}-0.2 x^{3}+424,964$ & 0.91 & 0.0006 \\
5 & $Y=269 x-1 x^{2}-15,486$ & 0.80 & 0.0359 \\
6 & $Y=-184 x+4,594$ & 0.42 & 0.2107 \\
7 & $Y=649 x-2 x^{2}-39,972$ & 0.12 & 0.0004 \\
8 & $Y=811 x-3 x^{2}-51,010$ & 0.67 & 0.0006 \\
9 & $Y=12 x+2,157$ & 0.68 & 0.1510 \\
10 & $Y=-8,242 x+63 x^{2}-0.2 x^{3}-357,310$ & 0.0196 \\
11 & $Y=745 x-3 x^{2}-50,809$ & 0.12 & 0.0027 \\
12 & $Y=808 x-3 x^{2}-52,084$ & 0.78 & 0.0024 \\
13 & $Y=13 x-477$ & 0.69 & 0.0682 \\
14 & $Y=6 x+1,610$ & 0.72 & 0.5596 \\
15 & $Y=-262 x+1 x^{2}+16,035$ & 0.17 & 0.0135 \\
16 & $Y=44 x-2,737$ & 0.02 & 0.0001 \\
17 & $Y=29 x-2,053$ & 0.94 & 0.0035 \\
\hline
\end{tabular}

TABLE 4: Average and standard deviation for peanut yield, percentages of extra large kernels (\%ELK) and total sound mature kernels (\%TSMK), days after peanut emergence, and heat unit accumulation for the date when yield was the highest over 5 digging dates for the cultivar Gregory from 2003 to 2012.

\begin{tabular}{lcc}
\hline Parameter & $\begin{array}{c}\text { Average for } \\
\text { parameter }\end{array}$ & $\begin{array}{c}\text { Standard } \\
\text { deviation }\end{array}$ \\
\hline Pod yield (kg/ha) & 5,320 & 1,814 \\
\%ELK & 52 & 8 \\
\%TSMK & 65 & 5 \\
Economic value (\$/ha) & 3,060 & 739 \\
Days after emergence & 138 & 8 \\
Heat unit accumulation & 2,767 & 183 \\
\hline
\end{tabular}

observed when peanut was dug in mid-October following 5 fungicide sprays compared with all other combinations of fungicide regime and digging date (Table 10). In the absence of fungicide, delaying digging from late September until early or mid-October increased economic return during 2005 but not 2006. When peanut was treated twice with fungicide, no difference in economic return was observed across digging dates.

The balance between pod maturation and the impact of canopy defoliation on economic value is important for growers to consider. Knauft et al. [12] reported that yield loss was greatest when poor disease control through genetic resistance was obtained while yields continued to increase with delayed digging for disease-resistant cultivars.
TABLe 5: Pearson correlations for canopy defoliation, pod yield, percentages of extra large kernels (\%ELK) and total sound mature kernels (\%TSMK), and economic value (\$/ha) in the experiment comparing digging dates and fungicide regimes with the cultivar Gregory for experiments conducted from 2005 to 2012.

\begin{tabular}{lcc}
\hline Parameters & $P>F$ & $R^{2}$ \\
\hline Pod yield versus defoliation & $<0.0001$ & -0.30 \\
\%ELK versus defoliation & 0.0002 & -0.18 \\
\%TSMK versus defoliation & 0.0150 & 0.12 \\
Economic value versus defoliation & 0.0006 & -0.18 \\
Pod yield versus \%ELK & $<0.0001$ & 0.28 \\
Pod yield versus \%TSMK & $<0.0001$ & 0.28 \\
Pod yield versus economic value & $<0.0001$ & 0.92 \\
\%ELK versus economic value & $<0.0001$ & 0.61 \\
\%TSMK versus economic value & $<0.0001$ & 0.45 \\
\hline
\end{tabular}

In a final set of comparisons, the efficacy of a late-season application of fungicide was compared when sprayed on diseased and nondiseased peanut. Although the interaction of year $\times$ fungicide regime $\times$ rescue fungicide was not significant of pod yield, \%ELK, \% TSMK, and economic value, of key interest is the interaction of trial $\times$ rescue treatment which was significant for pod yield and economic value (Table 11).

When pooled over fungicide regimes, one additional fungicide treatment in mid-September decreased canopy defoliation at the final digging date in 4 of 8 years by 11 to $18 \%$ (Table 12). Lack of a fungicide treatment by rescue treatment interaction suggests that decreased defoliation in these 
TABLE 6: Analysis of variance ( $F$-value) for percent canopy defoliation (\%), pod yield $(\mathrm{kg} / \mathrm{ha})$, percentages of extra large kernels (\%ELK) and total sound mature kernels (\%TSMK), and economic value $(\$ / \mathrm{ha})$ for the cultivar Gregory as influenced by the interaction of digging date and fungicide regime for experiments conducted from 2005 to 2012.

\begin{tabular}{|c|c|c|c|c|c|}
\hline Source of variation & Canopy defoliation & Pod yield & $\% \mathrm{ELK}$ & $\%$ TSMK & Economic value \\
\hline Year & $6.5^{*}$ & $28.1^{*}$ & $22.2^{*}$ & $31.5^{*}$ & $18.5^{*}$ \\
\hline Digging date (date) & $34.7^{*}$ & 0.6 & $32.0^{*}$ & $62.6^{*}$ & $8.5^{*}$ \\
\hline Year $\times$ date & $3.3^{*}$ & $2.1^{*}$ & 3.7 & $6.9^{*}$ & $2.6^{*}$ \\
\hline Fungicide & $197.1^{*}$ & $34.0^{*}$ & $5.5^{*}$ & 0.2 & $34.7^{*}$ \\
\hline Date $\times$ fungicide & $19.8^{*}$ & $2.8^{*}$ & 0.3 & 0.6 & $2.8^{*}$ \\
\hline Year $\times$ fungicide & $9.5^{*}$ & $5.9^{*}$ & 1.3 & 0.6 & $6.0^{*}$ \\
\hline Year $\times$ date $\times$ fungicide & $2.3^{*}$ & $1.9^{*}$ & 0.8 & 0.8 & $2.1^{*}$ \\
\hline Coefficient of variation (\%) & 57.7 & 12.5 & 7.5 & 3.9 & 15.9 \\
\hline
\end{tabular}

* indicates significance at $P<0.05$.

TABLE 7: Analysis of variance ( $F$-value) for percent canopy defoliation $(\%)$, pod yield $(\mathrm{kg} / \mathrm{ha})$, and economic value ( $\$ / \mathrm{ha})$ for the cultivar Gregory as influenced by the interaction of year, digging date, and fungicide regime.

\begin{tabular}{|c|c|c|c|}
\hline Source of variation & Canopy defoliation & Pod yield & Economic value \\
\hline \multicolumn{4}{|l|}{2005} \\
\hline Digging date (date) & $71.5^{*}$ & $11.9^{*}$ & $23.9^{*}$ \\
\hline Fungicide & $79.9^{*}$ & $6.8^{*}$ & $10.8^{*}$ \\
\hline Date $\times$ fungicide & $20.5^{*}$ & $2.8^{*}$ & $3.1^{*}$ \\
\hline Coefficient of variation (\%) & 37.3 & 11.6 & 11.5 \\
\hline \multicolumn{4}{|l|}{2006} \\
\hline Date & $157.3^{*}$ & $5.6^{*}$ & $5.5^{*}$ \\
\hline Fungicide & $504.9^{*}$ & $11.0^{*}$ & $12.2^{*}$ \\
\hline Date $\times$ fungicide & $53.3^{*}$ & $3.6^{*}$ & $5.2^{*}$ \\
\hline Coefficient of variation (\%) & 14.2 & 20.7 & 21.5 \\
\hline \multicolumn{4}{|l|}{2007} \\
\hline Date & 1.9 & 7.5 & 21.4 \\
\hline Fungicide & 0.9 & 0.9 & 0.4 \\
\hline Date $\times$ fungicide & 0.2 & 1.0 & 0.7 \\
\hline Coefficient of variation (\%) & 155.2 & 7.6 & 11.3 \\
\hline \multicolumn{4}{|l|}{2008} \\
\hline Date & $13.9^{*}$ & 1.6 & 0.6 \\
\hline Fungicide & $38.4^{*}$ & $12.4^{*}$ & $11.2^{*}$ \\
\hline Date $\times$ fungicide & $3.4^{*}$ & 1.8 & 1.6 \\
\hline Coefficient of variation (\%) & 48.0 & 16.0 & 18.2 \\
\hline \multicolumn{4}{|l|}{2009} \\
\hline Date & 1.9 & $8.0^{*}$ & $8.0^{*}$ \\
\hline Fungicide & $5.0^{*}$ & 1.2 & 2.3 \\
\hline Date $\times$ fungicide & 0.2 & 0.1 & 0.3 \\
\hline Coefficient of variation (\%) & 130.9 & 15.1 & 19.4 \\
\hline \multicolumn{4}{|l|}{2010} \\
\hline Date & $7.1^{*}$ & $7.0^{*}$ & 1.4 \\
\hline Fungicide & 2.8 & $6.7^{*}$ & $7.7^{*}$ \\
\hline Date $\times$ fungicide & 1.0 & 1.3 & 1.1 \\
\hline Coefficient of variation (\%) & 96.5 & 13.4 & 15.9 \\
\hline \multicolumn{4}{|l|}{2011} \\
\hline Date & $17.0^{*}$ & 0.8 & 3.1 \\
\hline Fungicide & $45.3^{*}$ & 0.8 & 0.8 \\
\hline Date $\times$ fungicide & $3.4^{*}$ & 0.4 & 0.5 \\
\hline Coefficient of variation (\%) & 51.5 & 20.4 & 23.2 \\
\hline \multicolumn{4}{|l|}{2012} \\
\hline Date & $5.0^{*}$ & 1.4 & $4.8^{*}$ \\
\hline Fungicide & $9.7^{*}$ & $9.9^{*}$ & $12.4^{*}$ \\
\hline Date $\times$ fungicide & 1.8 & 0.9 & 1.1 \\
\hline Coefficient of variation (\%) & 94.2 & 10.4 & 12.1 \\
\hline
\end{tabular}

* indicates significance at $P<0.05$. 
TABLE 8: Canopy defoliation as influenced main effects of digging date and fungicide regime and the interaction of year, digging date, and fungicide regime* ${ }^{*}$.

\begin{tabular}{|c|c|c|c|c|}
\hline \multirow{3}{*}{ Digging dates } & \multicolumn{4}{|c|}{$\begin{array}{c}\text { Canopy defoliation } \\
\text { Number of fungicide sprays }\end{array}$} \\
\hline & 0 & 2 & 5 & $\begin{array}{l}\text { Pooled over } \\
\text { fungicide sprays }\end{array}$ \\
\hline & \multicolumn{4}{|c|}{$\%$} \\
\hline \multicolumn{5}{|l|}{2005} \\
\hline September 20-24 & $8^{\mathrm{cd}}$ & $4^{\mathrm{cd}}$ & $0^{c}$ & - \\
\hline October 3-8 & $46^{\mathrm{b}}$ & $15^{\mathrm{c}}$ & $0^{c}$ & - \\
\hline October 15-19 & $79^{\mathrm{a}}$ & $58^{\mathrm{b}}$ & $0^{\mathrm{c}}$ & - \\
\hline \multicolumn{5}{|l|}{2006} \\
\hline September 20-24 & $41^{\mathrm{c}}$ & $11^{\mathrm{e}}$ & $1^{\mathrm{e}}$ & - \\
\hline October 3-8 & $60^{\mathrm{b}}$ & $26^{\mathrm{d}}$ & $0^{\mathrm{e}}$ & - \\
\hline October 15-19 & $79^{\mathrm{a}}$ & $74^{\mathrm{a}}$ & $0^{\mathrm{e}}$ & - \\
\hline \multicolumn{5}{|l|}{2008} \\
\hline September 20-24 & $20^{\mathrm{b}}$ & $15^{\mathrm{bc}}$ & $0^{\mathrm{d}}$ & - \\
\hline October 3-8 & $49^{\mathrm{a}}$ & $23^{\mathrm{b}}$ & $1^{\mathrm{d}}$ & - \\
\hline October 15-19 & $59^{\mathrm{a}}$ & $47^{\mathrm{a}}$ & $4^{\mathrm{cd}}$ & - \\
\hline \multicolumn{5}{|l|}{2010} \\
\hline September 20-24 & - & - & - & $23^{\mathrm{a}}$ \\
\hline October 3-8 & - & - & - & $8^{\mathrm{b}}$ \\
\hline October 15-19 & - & - & - & $12^{\mathrm{a}}$ \\
\hline \multicolumn{5}{|l|}{2011} \\
\hline September $20-24$ & $20^{c}$ & $1^{\mathrm{d}}$ & $0^{\mathrm{d}}$ & - \\
\hline October 3-8 & $41^{\mathrm{b}}$ & $18^{\mathrm{c}}$ & $2^{\mathrm{d}}$ & - \\
\hline October $15-19$ & $59^{\mathrm{a}}$ & $31^{\mathrm{b}}$ & $3^{\mathrm{d}}$ & - \\
\hline \multicolumn{5}{|l|}{2012} \\
\hline September 20-24 & - & - & - & $13^{\mathrm{b}}$ \\
\hline October 3-8 & - & - & - & $10^{\mathrm{b}}$ \\
\hline October 15-19 & - & - & - & $30^{\mathrm{a}}$ \\
\hline
\end{tabular}

${ }^{*}$ Means within a year followed by the same letter are not statistically different according to Fisher's protected LSD test at $P \leq 0.05$.

TABLE 9: Canopy defoliation and economic return as influenced by fungicide regime*.

\begin{tabular}{lccccc}
\hline $\begin{array}{l}\text { Fungicide } \\
\text { sprays }\end{array}$ & \multicolumn{2}{c}{ Canopy defoliation } & \multicolumn{3}{c}{ Economic value } \\
Number & 2009 & 2012 & 2008 & 2010 & 2012 \\
\hline 0 & \multicolumn{2}{c}{$\%$} & & $\$ /$ ha & \\
2 & $28^{\mathrm{a}}$ & $33^{\mathrm{a}}$ & $1,788^{\mathrm{b}}$ & $989^{\mathrm{b}}$ & $2,004^{\mathrm{b}}$ \\
5 & $8^{\mathrm{b}}$ & $17^{\mathrm{b}}$ & $2,392^{\mathrm{a}}$ & $1,078^{\mathrm{b}}$ & $2,204^{\mathrm{b}}$ \\
\hline
\end{tabular}

${ }^{*}$ Means within a year followed by the same letter are not statistically different according to Fisher's protected LSD test at $P \leq 0.05$. Data are pooled over digging dates.

4 years occurred for both diseased peanut and peanut with relatively little disease as provided by the 5 -spray fungicide regime. The decrease in canopy defoliation resulted in an
TABLE 10: Economic value as influenced by the interaction of digging date and fungicide regime and the main effect of digging date* .

\begin{tabular}{lcccc}
\hline & \multicolumn{5}{c}{ Economic value } \\
Digging dates & 0 & 2 & 5 & $\begin{array}{c}\text { Pooled over } \\
\text { fungicide sprays }\end{array}$ \\
& \multicolumn{5}{c}{$\$ /$ ha } & \\
\hline 2005 & & & & - \\
September 20-24 & $767^{\mathrm{c}}$ & $927^{\mathrm{bc}}$ & $901^{\mathrm{bc}}$ & - \\
October 3-8 & $1,005^{\mathrm{bc}}$ & $914^{\mathrm{bc}}$ & $1,138^{\mathrm{b}}$ & - \\
October 15-19 & $1,023^{\mathrm{bc}}$ & $1,157^{\mathrm{b}}$ & $1,413^{\mathrm{a}}$ & - \\
\hline 2006 & & & & - \\
September 20-24 & $1,430^{\mathrm{c}}$ & $1,321^{\mathrm{cd}}$ & $1,382^{\mathrm{cd}}$ & - \\
October 3-8 & $1,575^{\mathrm{c}}$ & $1,329^{\mathrm{cd}}$ & $1,950^{\mathrm{b}}$ & - \\
October 15-19 & $1,296^{\mathrm{d}}$ & $1,504^{\mathrm{c}}$ & $2,703^{\mathrm{a}}$ & - \\
\hline 2009 & & & & $1,375^{\mathrm{ab}}$ \\
September 20-24 & - & - & - & $1,514^{\mathrm{a}}$ \\
October 3-8 & - & - & - & $1,100^{\mathrm{b}}$ \\
\hline October 15-19 & - & - & - & -
\end{tabular}

${ }^{*}$ Means within a year followed by the same letter are not statistically different according to Fisher's protected LSD test at $P \leq 0.05$. Data for 2009 are pooled over fungicide regimes.

increase in economic value only in 2011. In contrast, economic value in 2006 decreased when the rescue treatment was applied. Sclerotinia blight (caused by Sclerotinia minor) is present at this location. Applying chlorothalonil when Sclerotinia blight is active can increase disease [23] as a result of increased virulence of Sclerotinia minor in the presence of chlorothalonil [24]. Although not substantiated, the decrease in yield may have been associated with negative impact of Sclerotinia blight caused by chlorothalonil plus pyraclostrobin.

\section{Conclusions}

Results for both of these experiments emphasize the value of timely digging under disease-free conditions. These results also suggest that, under conditions where disease is poorly controlled, peanut yield is often similar when peanut is dug earlier than typically expected based on mesocarp color, most likely because of pod shed in the presence of disease. While not surprising, protecting peanut from disease and delaying digging until optimum pod maturation occurs continue to be two of the most effective ways to optimize peanut yield. Results also suggest that while rescue or salvage applications of fungicide prevent further defoliation caused by leaf spot disease, economic value will not always be protected.

\section{Competing Interests}

None of the authors have competing interests in terms of products mentioned in the paper. 
TABLE 11: Analysis of variance ( $F$-value) for percent canopy defoliation, pod yield, percentages of extra large kernels (\%ELK) and total sound mature kernels (\%TSMK), and economic value for the cultivar Gregory as influenced by the interaction of fungicide regime and late-season rescue application of fungicides for experiments conducted from 2005 to 2012.

\begin{tabular}{|c|c|c|c|c|c|}
\hline Source of variation & Canopy defoliation & Yield & $\% \mathrm{ELK}$ & $\% \mathrm{TSMK}$ & Economic value \\
\hline Year & $7.0^{*}$ & $19.2^{*}$ & $26.4^{*}$ & $60.1^{*}$ & $18.2^{*}$ \\
\hline Fungicide & $155.0^{*}$ & $34.6^{*}$ & 1.4 & 0.7 & $36.7^{*}$ \\
\hline Rescue treatment (rescue) & $10.5^{*}$ & 2.2 & 0.4 & 0.8 & 0.8 \\
\hline Fungicide $\times$ rescue & 1.7 & 0.3 & 0.7 & 0.7 & 0.3 \\
\hline Year $\times$ fungicide & $8.4^{*}$ & $8.2^{*}$ & $1.8^{*}$ & 0.6 & $9.5^{*}$ \\
\hline Year $\times$ rescue & $2.7^{*}$ & $5.1^{*}$ & 0.9 & 1.2 & $3.2^{*}$ \\
\hline Year $\times$ fungicide $\times$ rescue & 1.4 & 1.3 & 1.1 & 0.9 & 1.0 \\
\hline Coefficient of variation (\%) & 51.2 & 14.1 & 8.1 & 4.0 & 17.3 \\
\hline
\end{tabular}

* indicates significance at $P<0.05$.

TABLE 12: Canopy defoliation and economic return following lateseason rescue application of fungicides for each year.

\begin{tabular}{lcccc}
\hline & \multicolumn{4}{c}{ Rescue application of fungicides } \\
Year & Canopy defoliation & \multicolumn{2}{c}{ Economic value } \\
& No & Yes & No & Yes \\
& & $\%$ & & \multicolumn{3}{c}{$\$ /$ ha } \\
\hline 2005 & 45 & $27^{*}$ & 1,198 & 1,103 \\
2006 & 51 & $38^{*}$ & 1,834 & $1,549^{*}$ \\
2007 & 3 & 3 & 2,088 & 2,181 \\
2008 & 37 & 45 & 2,266 & 2,309 \\
2009 & 12 & 15 & 1,100 & 1,141 \\
2010 & 34 & $21^{*}$ & 1,089 & 1,033 \\
2011 & 31 & $20^{*}$ & 1,770 & $2,249^{*}$ \\
2012 & 30 & 23 & 2,412 & 2,501 \\
\hline
\end{tabular}

* indicates a difference within a year at $P<0.05$. Data are pooled over fungicide regimes. Rescue fungicide treatment consisted of chlorothalonil plus pyraclostrobin at $0.5 \mathrm{~kg} / \mathrm{ha}$ and $0.11 \mathrm{~kg} / \mathrm{ha}$, respectively.

\section{Acknowledgments}

This research was supported financially by the North Carolina Peanut Growers Association Inc., the National Peanut Board, and the USAID Peanut CRSP LAG-00-96-90013-00. Technical assistance was provided by staff at the Peanut Belt Research Station.

\section{References}

[1] R. W. Mozingo, T. A. Coffelt, and F. S. Wright, "The influence of planting and digging dates on yield, value, and grade of four virginia-type peanut cultivars," Peanut Science, vol. 18, no. 1, pp. 55-62, 1991.

[2] W. A. Court, R. C. Roy, and J. G. Hendel, "Effect of harvest date on agronomic and chemical characteristics of ontario peanuts," Canadian Journal of Plant Science, vol. 64, no. 3, pp. 521-528, 1984.

[3] C. T. Young, R. S. Matlock, M. E. Mason, and G. R. Waller, "Effect of harvest date and maturity upon free amino acid levels in three varieties of peanuts," Journal of the American Oil Chemists Society, vol. 51, no. 6, pp. 269-273, 1974.
[4] M. A. Awal and L. Aktan, "Effect of row spacing on growth and yield of peanut (Arachis hypogaea L.) stands," International Journal of Agriculture, Forestry, and Fisheries, vol. 3, pp. 7-11, 2015.

[5] M. J. Hinds, B. Singh, and J. C. Anderson, "Determination of pod and crop maturity for peanuts using percent pod-fill," Canadian Journal of Plant Science, vol. 72, no. 4, pp. 1057-1065, 1992.

[6] K. J. Boote, "Growth stages of peanut (Arachis hypogaea L.)," Peanut Science, vol. 9, no. 1, pp. 35-40, 1982.

[7] A. C. Mixon and W. D. Branch, "Agronomic performance of a Spanish and runner cultivar harvested at six different digging intervals," Peanut Science, vol. 12, no. 1, pp. 50-54, 1985.

[8] T. H. Sanders, A. M. Schubert, and H. E. Pattee, "Maturity methodology and postharvest physiology," in Peanut Science and Technology, pp. 624-654, American Peanut Research and Education Society, 1995.

[9] E. J. Williams and J. S. Drexler, "A non-destructive method for determining peanut pod maturity," Peanut Science, vol. 8, no. 2, pp. 134-141, 1981.

[10] C. E. Holiday, E. J. Williams, and V. Chew, "A method for estimating peanut maturity," Journal of Food Science, vol. 44, no. 1, pp. 254-256, 1979.

[11] D. L. Rowland, R. B. Sorensen, C. L. Butts, and W. H. Faircloth, "Determination of maturity and degree day indices and their success in predicting peanut maturity," Peanut Science, vol. 33, no. 2, pp. 125-136, 2006.

[12] D. A. Knauft, D. W. Gorbet, and A. J. Norden, "Yield and market quality of seven peanut genotypes as affected by leafspot disease and harvest date," Peanut Science, vol. 15, no. 1, pp. 9-13, 1988.

[13] D. S. Carley, D. L. Jordan, B. B. Shew, T. B. Sutton, L. C. Dharmasri, and R. L. Brandenburg, "Influence of digging date and fungicide program on canopy defoliation and pod yield of peanut (Arachis hypogaea L.)," Peanut Science, vol. 36, no. 1, pp. 77-84, 2009.

[14] J. W. Chapin and J. S. Thomas, "Effect of fungicide treatments, pod maturity, and pod health on peanut peg strength," Peanut Science, vol. 32, no. 2, pp. 119-125, 2005.

[15] B. Shew, Peanut Disease Management, Peanut Information, 2014.

[16] A. K. Culbreath, R. C. Kemerait Jr., and T. B. Brenneman, Management of Early Leaf Spot of Peanut as Affected by Fungicide and Date of Spray Program Initiation, Plant Health Progress, 2005. 
[17] T. G. Isleib, P. W. Rice, R. W. Mozingo, R. W. Mozingo, and H. E. Pattee, "Registration of 'Gregory' peanut," Crop Science, vol. 39, no. 5, p. 1526, 1999.

[18] USDA, Peanut Inspection Program, US Government Print Office, 2005.

[19] S. G. Bullen and D. Jordan, "Peanut production budgets," in 2016 Peanut Information, pp. 7-18, NC State University, 2016.

[20] SAS, "Proc GLM procedure," Version 9.4, SAS Institute, 20022012.

[21] SAS, "Proc Reg procedure," Version 9.4, SAS Institute, 20022012.

[22] SAS, "Proc Corr procedure," Version 9.4, SAS Institute, 20022012.

[23] D. M. Porter, "Increased severity of sclerotinia blight in peanuts treated with captafol and chlorothalonil," Plant Disease, vol. 64, no. 4, pp. 394-395, 1980.

[24] F. C. Hau and M. K. Beute, "Effects of chlorothalonil on the virulence and physiology of a nonargeted pathogen, Sclerotinia minor," Phytopathology, vol. 73, pp. 475-479, 1983. 


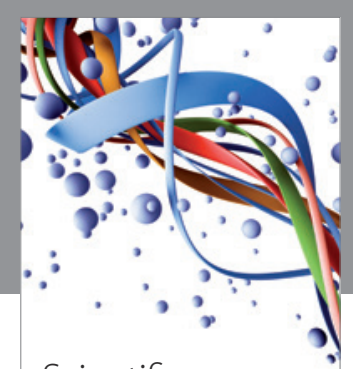

Scientifica
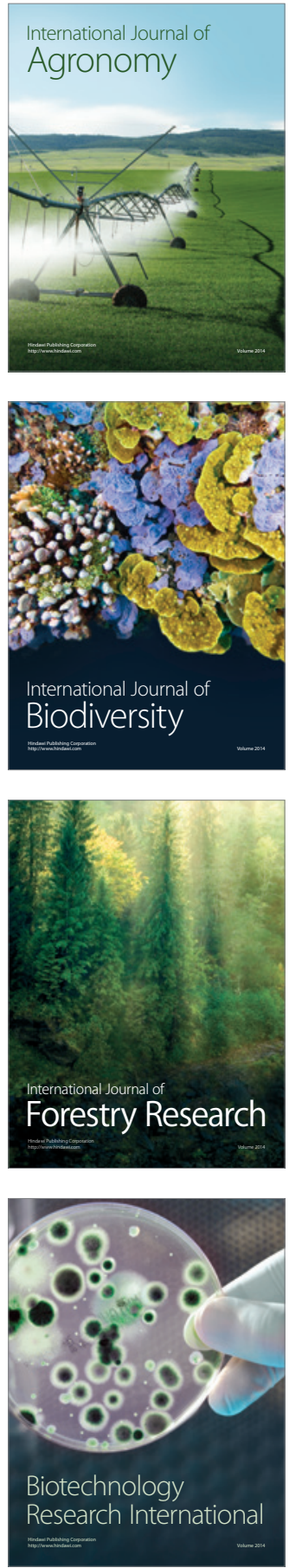
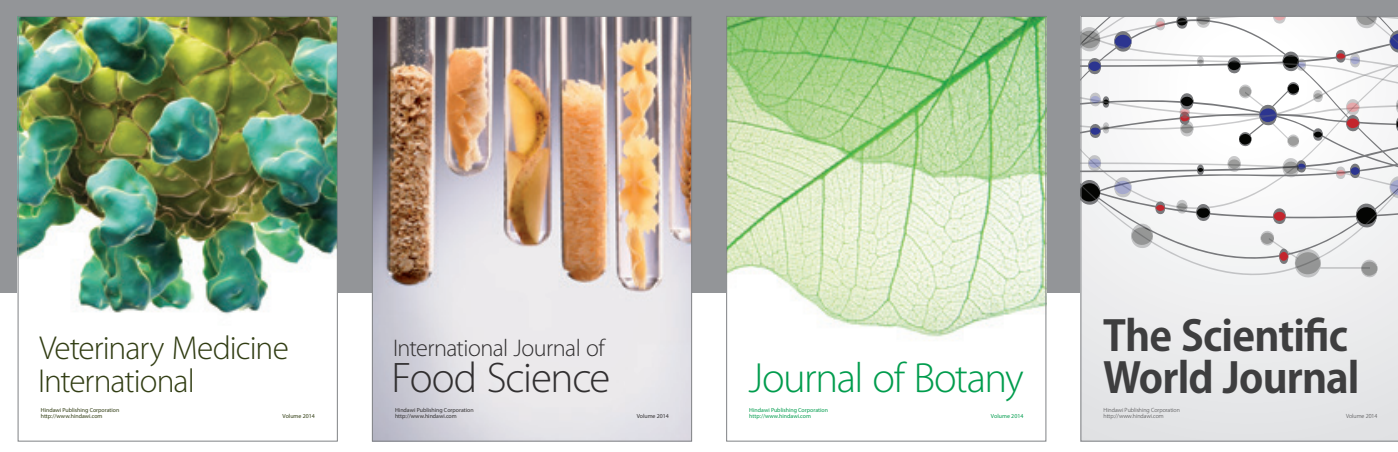

The Scientific

\section{World Journal}

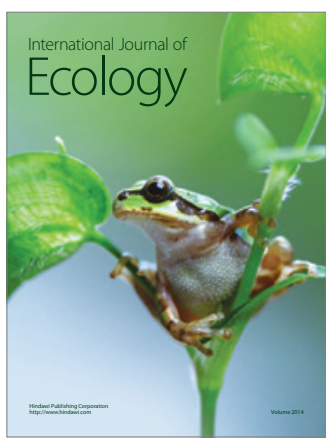

\section{Hindawi}

Submit your manuscripts at

http://www.hindawi.com
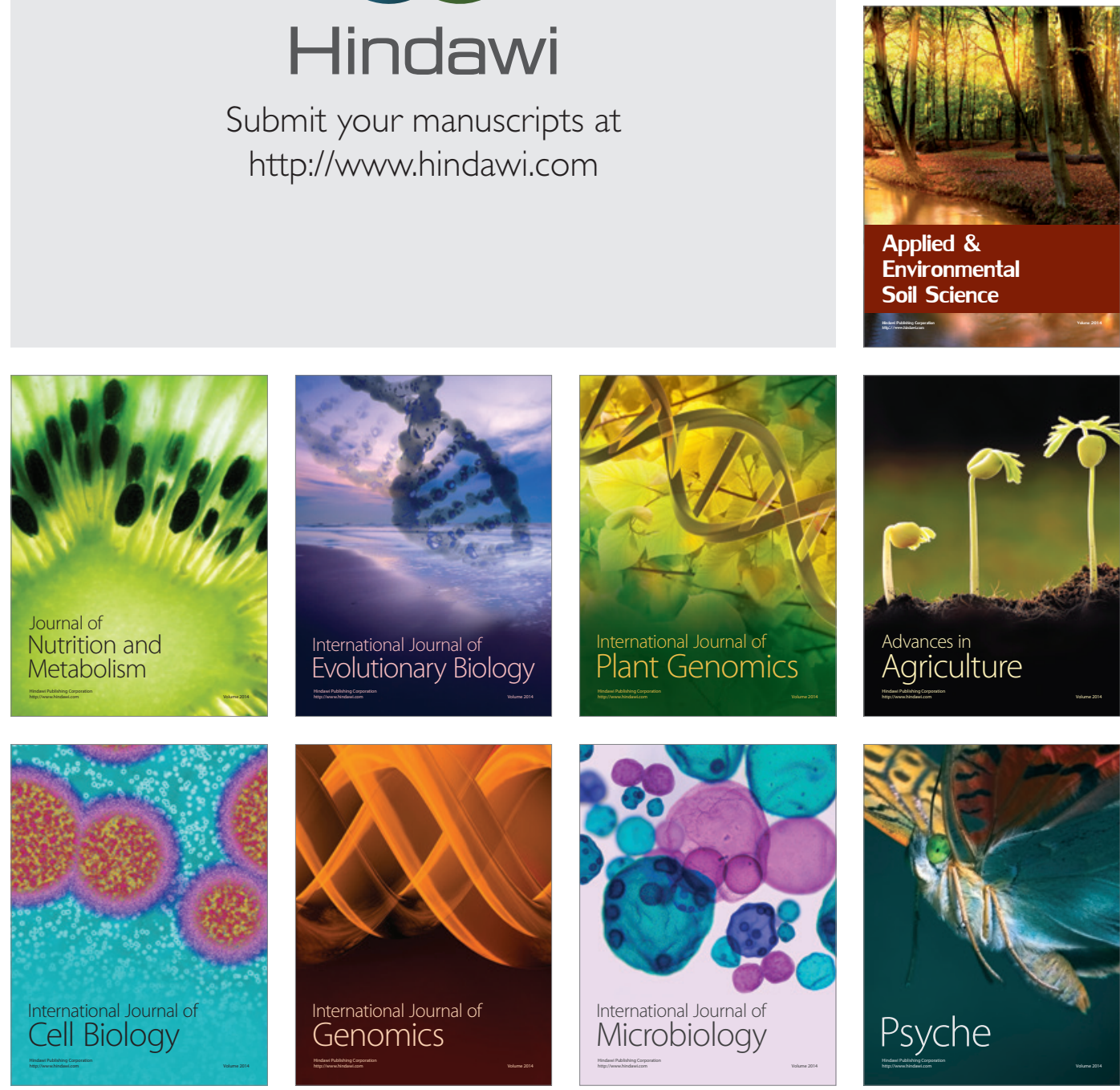
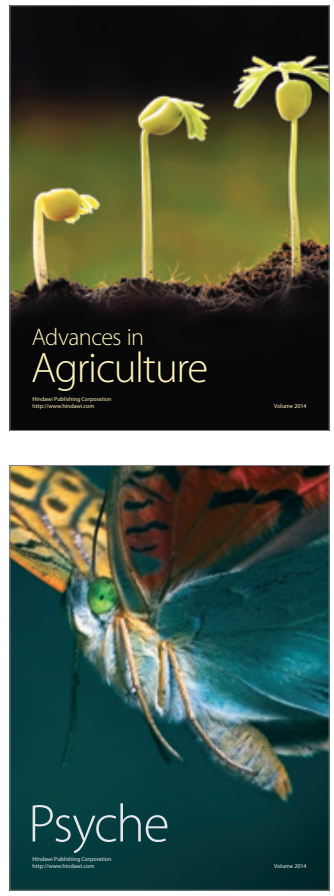